\title{
PENDEKATAN BALANCED SCORECARD (BSC) UNTUK PENGUKURAN KINERJA PERUSAHAAN POULTRY SHOP BAROKAH.
}

\author{
Alfan Syururi \\ Teknik Industri, Fakultas Teknik \\ Universitas Maarif Hasyim Latif, Sidoarjo, Indonesia \\ e-mail : alfan-syururi@student.umaha.ac.id
}

\section{ABSTRAK}

Pendekatan metode Balanced Scorecard dalam penelitian ini dilakukan pada Poultry Shop Barokah yang berlokasi di Dusun Temboro, Desa Plaosan, Kecamatan Wates, Kabupaten Kediri. Poultry Shop Barokah adalah salah satu sektor peternakan yang memiliki peran penting dalam kehidupan dan pengembangan sumber daya di wilayah sekitar Kabupaten Kediri. Berfungsi sebagai penyedia sumber protein untuk memenuhi kebutuhan pangan. Sumber protein dengan harga murah dan terjangkau. Berbagai menu olahan telur ayam dapat dimasak dengan mudah dan juga memiliki rasa yang enak. Tingginya permintaan pasar akan telur ayam membuat persaingan dalam usaha ternak telur ayam semakin melonjak, untuk meningkatkan hasil perusahaan diperlukan strategi dalam pengukuran kinerja. Berbagai pendekatan yang akan dilakukan bertujuan untuk mengetahui kinerja pada Poultry Shop Barokah dengan menggunakan metode Balanced Scorecard. Pengumpulan data yang dilakukan pada Poultry Shop Barokah adalah dengan menggunakan dokumentasi, kuesioner dan wawancara.

Kata kunci: Balanced Scorecard, Optimalisasi kinerja

\section{PENDAHULUAN}

Penilaian kinerja yang paling mudah umumnya dilakukan oleh perusahaan adalah menggunakan pengukuran dengan sumber pendekatan tradisional yaitu suatu pengukuran yang berbasis dari perspektif keuangan saja. Keuntungan dari pengukuran kinerja diatas sangatlah mudah sehingga banyak perusahaan yang menggunakan alternatif tersebut. Pendekatan tradisional mempunyai banyak kelemahan seperti hanya berorientasi pada keuntungan jangka pendek bukan dalam jangka panjang, dalam pendekatan ini tidak dapat menilai kekayaan suatu perusahaan yang tidak berwujud.

Balanced Scorecard, adalah keseimbangan antara keuangan dan non keuangan, antara jangka pendek dan jangka panjang, dan antara prestasi yang bersifat internal dan prestasi yang bersifat eksternal. Scorecard adalah kartu untuk mencatat skor prestasi seseorang, dengan Balanced Scorecard kelemahan-kelemahan tersebut dapat diatasi dengan cara memeriksa setiap perspektif, sehingga kelemahan yang disebutkan diatas dapat dikurangi. Peternakan ayam ras petelur Poultry Shop Barokah adalah salah satu usaha yang terletak di Desa Plaosan Kecamatan Wates Kabupaten Kediri. Poultry Shop merupakan perusahaan yang dominan bergerak dibidang penjualan pakan ternak unggas, menjual bibit ayam petelur (putuk), obat-obatan ternak dan berbagai peralatan peternakan ayam ras petelur. Poultry Shop Barokah memiliki kandang dengan kapasitas 160.000 ekor. Jumlah ayam yang sudah sudah bisa dikatakan tidak sedikit namun Poultry Shop Barokah masih menerapkan pendekatan tradisional dalam penilaian kinerja. Berdasarkan latar belakang usaha tersebut maka perlu dilakukan suatu penerapan atau pendekatan konsep metode Balanced Scorecard, guna mengetahui prospek kedepan, pengukuran kinerja, kerugian-kerugian atau pengeluaran-pengeluaran yang tidak perlu pada peternakan ayam ras petelur Poultry Shop Barokah.

\section{METODE PENELITIAN}

Variabel yang ada dalam penelitian ini untuk mengukur kinerja masing-masing perspektif adalah :

1. Perspektif Keuangan

a. Current Ratio adalah kemampuan untuk membayar hutang selama yang segera harus dipenuhi dengan aktiva lancar. Merupakan asset jangka pendek (aktiva lancar) dibagi dengan hutang jangka pendek, dinyatakan dalam persen. (Widjaja, 2001b)

b. Profit Margin merupakan keuntungan bersih dibagi penjualan bersih, dan dinyatakan dalam persentase. (Kaplan, Robert, S., \& Norton, David, 1992)

c. Operating Ratio merupakan biaya operasi dibagi dengan penjualan bersih , dan dinyatakan dalam persen. Biaya Operasi sendiri terdiri dari harga pokok penjualan ditambah dengan biaya usaha. (Nair, 2014)

d. Return on Invesment (ROI) adalah kemampuan dari modal yang digunakankan untuk seluruh 
aktiva yang menghasilkan laba bersih. Merupakan rasio keuntungan bersih terhadap total asset di nyatakan dalam persen.

\section{Perspektif Pelanggan}

a. Tingkat Pemerolehan Pelanggan yaitu seberapa besar pelanggan baru yang di dapatkan perusahaan, dengan rumus jumlah total pelanggan baru dibagi dengan jumlah total keseluruhan pelanggan dan dikalikan 100\%.

b. Tingkat Retensi (Customer Retention) yaitu untuk menilai perusahaan berhasil tidaknya dalam menjaga pelanggan lama, dengan rumus jumlah total pelanggan lama dibagi dengan jumlah total keseluruhan pelanggan dan dikalikan 100\%.

c. Tingkat Kepuasan Pelanggan adalah kepuasan pelanggan mengukur seberapa jauh pelanggan merasa puas terhadap layanan perusahan.

d. Tingkat Profitabilitas Pelanggan yaitu pengukuran besarnya keuntungan yang dicapai perusahaan dari produk yang dijual kepada pelanggan. (Fadillah, Arizon, Adriansyah, Fudhla, \& Dwi, 2019)

3. Perspektif Bisnis Internal

a. Inovasi, yaitu untuk mengetahui jasa atau produk yang ditawarkan dibandingkan dengan jumlah produk atau jasa perusahaan yang telah ada.

b. Pelayanan Purna Jual, adalah bentuk layanan yang diberikan perusahaan supaya memberikan manfaat tambahan terhadap pelanggan atau konsumen.

4. Perspektif Pembelajaran dan Pertumbuhan

a. Kepuasan karyawan, mengukur tingkat kepuasan karyawan penelitian ini dilaksanakan dengan cara survey kepuasan karyawan dengan menggunakan kuesioner yang nantinya di bagikan kepada karyawan Poultry Shop Barokah. (Mooraj, 1999)

b. Retensi karyawan, yaitu kemampuan perusahaan dalam mempertahankan karyawannya dengan cara membagi jumlah karyawan yang keluar dengan jumlah seluruh karyawan pada tahun 2013 sampai tahun 2017 (Kaplan, Robert, S., \& Norton, David, 1992)

c. Produktivitas karyawan, mengetahui produktivitas karyawan dalam periode tertentu dengan cara membandingkan keuntungan jasa terhadap jumlah total karyawan selama tahun 2013 sampai tahun 2017. (Mulyadi dan Setyawan Johny, 2000)
Ada tiga sasaran keuangan yang bisa sangat berbeda disetiap tahapannya dari siklus kehidupan bisnis. Tahapan siklus tersebut antara lain adalah bertumbuh (growth), bertahan (sustain) dan menuai (harvest). Maka dapat disimpulkan bahwa tolok ukur perspektif keuangan pada Poultry Shop Barokah dikatakan sudah tercapai yaitu jika keuntungan (profit) perusahaan selalu meningkat dan berkelanjutan dengan standar rata-rata dapat mencapai $10 \%$, supaya perusahaan bisa bertahan atau bahkan dapat lebih berkembang. (Sumanto, 1995)

\section{Perspektif Pelanggan}

Dalam perspektif pelanggan terdapat empat tolok ukur. Maka dari empat tolok ukur tersebut dapat diambil kesimpulan bahwa indikator perspektif pelanggan pada Poultry Shop Barokah dikatakan baik jika pangsa pasar dari Poultry Shop Barokah setiap tahun selalu mengalami peningkatan, hasil perhitungan retensi pelanggan setiap tahunnya mengalami penurunan dengan rata-rata 0,05\%, akuisisi atau jumlah pelanggan baru mengalami kenaikan pertahun dan hasil kuesioner pelanggan menyatakan puas terhadap pelayanan yang diberikan Poultry Shop Barokah.

3. Perspektif Bisnis Internal

Perspektif ini terdiri dari 2 tolok ukur yaitu inovasi dan pelayanan kepada pelanggan. Maka perspektif Bisnis internal pada Poultry Shop Barokah dikatakan baik jika jumlah inovasi perusahaan setiap tahunnya selalu bertambah dan adanya layanan klaim untuk mengganti barang cacat, rusak, atau kesalah pahaman pada saat proses pengiriman.

4. Perspektif Pertumbuhan dan Pembelajaran Pekerjaan karyawan dinilai berdasarkan faktorfaktor yang dianggap penting bagi pelaksanaan pekerjaan tersebut. Adapun faktor-faktor yang dijadikan indikator pengukuran kinerja pada karyawan adalah tingkat karyawan merasakan kepuasan, seberapa lama karyawan bertahan di dalam perusahaan, serta produktivitas karyawan. Maka dari tiga tolok ukur tersebut dapat diambil kesimpulan. Bahwa perspektif pertumbuhan dan pembelajaran pada Poultry Shop Barokah dapat dikatakan baik jika, karyawan merasa puas terhadap pelayanan yang diberikan Poultry Shop Barokah, hasil perhitungan dari retensi karyawan setiap tahunnya mengalami penurunan dengan rata-rata kurang dari 0,05\%, dan nilai produktifitas karyawan meningkat setiap tahunnya. 
1. Perspektif Keuangan

a) Return On Equity (ROE), dengan rumus sebagai berikut:

$$
\mathrm{ROE}=\frac{\text { Laba setelah pajak }}{\text { Modal sendiri }} \times 100 \%
$$

ROE dilakukan untuk menghasilkan laba dengan cara mengukur kemampuan perusahaan berdasarkan modal sendiri yang dimiliki perusahaan. ROE merupakan salah satu analisis rasio yang sering digunakan untuk menggambarkan kondisi keuangan perusahaan, karena dari rasio ini dapat menggambarkan kepentingan

\begin{tabular}{|c|c|c|c|}
\hline Tahun & $\begin{array}{l}\text { Laba bersih } \\
\text { setelah pajak (1) }\end{array}$ & Modal sendiri (2) & $\begin{array}{l}\text { ROE } \\
(3)=(1):(2) \\
\times 100 \%\end{array}$ \\
\hline 2013 & Rp 6.973.000.000 & Rp 89.700.000.000 & $7,7 \%$ \\
\hline 2014 & $\operatorname{Rp} 7.970 .000 .000$ & Rp 92.700.000.000 & $8,6 \%$ \\
\hline 2015 & Rp 8.465.000.000 & Rp 93.500.000.000 & $9 \%$ \\
\hline 2016 & Rp 8.963.300.000 & Rp 96.700.000.000 & $9,2 \%$ \\
\hline 2017 & Rp 10.459.800.000 & Rp 98.300.000.000 & $10,6 \%$ \\
\hline
\end{tabular}
pemegang saham.

Tabel 1. Perhitungan ROE Poultry Shop Barokah

Dari tabel 1 dapat diketahui laba bersih Poultry Shop Barokah sebelum dikenakan pajak dan laba bersih setelah dikenakan pajak mulai tahun 2013 sampai tahun 2017. Pajak pada Poultry Shop Barokah tidak terlalu besar mengingat luas perusahaan dan laba bersih perusahaan yang sangat besar, hal ini dikarenakan perusahaan hanya dikenakan pajak bumi bangunan (PBB) dan pajak kendaraan bermotor saja

tanpa adanya pajak perusahaan karena perusahaan ini tidak mempunyai legalitas atau badan hukum.

b) Return On Investment (ROI),

$$
\text { ROI }=\frac{\text { Laba setelah pajak }}{\text { Total Asset }} \times 100 \%
$$

\begin{tabular}{|c|c|c|c|}
\hline Tahun & $\begin{array}{l}\text { Laba bersih } \\
\text { setelah pajak } \\
\text { (1) }\end{array}$ & Total Asset (2) & $\begin{array}{l}\text { ROI (3) }= \\
(1):(2) x \\
100 \%\end{array}$ \\
\hline 2013 & Rp 6.973.000.000 & Rp 89.700.000.000 & $7,7 \%$ \\
\hline 2014 & Rp 7.970.000.000 & Rp 92.700.000.000 & $8,6 \%$ \\
\hline 2015 & Rp 8.465.000.000 & Rp 93.500.000.000 & $9 \%$ \\
\hline 2016 & Rp 8.963.300.000 & Rp 96.700.000.000 & $9,2 \%$ \\
\hline 2017 & Rp10.459.800.000 & Rp 98.300.000.000 & $10,6 \%$ \\
\hline
\end{tabular}

Tabel 2. Return On Investment

ROI merupakan suatu ukuran laba atas investasi. Tujuan

dari perusahaan yang mengutamakan laba. Instrument ini mendapat perhatian lebih dari investor sebab berhubungan dengan perputaran investasi mereka.

c) ProfitMargin, diperoleh dari selisih penjualan bersih dikurangi hpp dibagi penjualan bersih. Maka perusahaan sangat menginginkan profit margin yang besar karena profit yang besar menghasilkan laba yang besar juga. Berikut adalah rumus yang digunakan :

Profit Margin $=\frac{\text { Laba bersih }}{\text { Penjualan }} \times 100 \%$

Tabel 3. Profit Margin

\begin{tabular}{|l|l|l|l|}
\hline Tahun & $\begin{array}{l}\text { Laba bersih setelah } \\
\text { pajak (1) }\end{array}$ & Penjualan (2) & $\begin{array}{l}\text { Profit } \\
\text { margin (3) } \\
\text { = (1) : (2) x } \\
\mathbf{1 0 0 \%}\end{array}$ \\
\hline 2013 & Rp 6.973.000.000 & Rp 36.300.000.000 & $19,20 \%$ \\
\hline 2014 & Rp 7.970.000.000 & Rp 39.500.000.000 & $20,18 \%$ \\
\hline 2015 & Rp 8.465.000.000 & Rp 40.900.000.000 & $20,70 \%$ \\
\hline 2016 & Rp 8.963.300.000 & Rp 41.100.000.000 & $21,80 \%$ \\
\hline 2017 & Rp10.459.800.000 & Rp 45.200.000.000 & $23,14 \%$ \\
\hline
\end{tabular}

2. Perspektif Pelanggan

a) Pangsa Pasar

Berikut adalah data pangsa pasar yang telah dijangkau oleh Poultry Shop Barokah :

Tabel 4. Model Pengiriman Barang Kepada Pelanggan

\begin{tabular}{|l|c|l|l|}
\hline & $\begin{array}{l}\text { Jumlah } \\
\text { Kota }\end{array}$ & Pengiriman & $\begin{array}{l}\text { Estimasi } \\
\text { Sampai Tujuan }\end{array}$ \\
\hline Area Jawa & 3 & $\begin{array}{l}\text { Kurir } \\
\text { Perusahaan }\end{array}$ & 1-3 Hari \\
\hline Area Luar Jawa & 5 & $\begin{array}{l}\text { Kurir } \\
\text { Perusahaan }\end{array}$ & 3-5 Hari \\
\hline
\end{tabular}

Dari tabel diatas dapat diketahui pengiriman kepada pelanggan area jawa maupun area luar jawa sama-sama menggunakan kurir perusahaan dengan estimasi waktu yang berbeda-beda karena faktor jarak dan kondisi jalan.

b) Retensi Pelanggan

pengukuran ini dilaksanakan supaya dapat diketahui perusahaan mampu apa tidak untuk mempertahankan hubungannya dengan konsumen atau pelanggan. Dan dapat diketahui rata-rata dari pengumpulan data diatas adalah 86 Pelanggan. Dari rata-rata jumlah pelanggan diatas maka dapat diketahui jumlah rata-rata total tingkat retensi pelanggan Poultry Shop Barokah.

Dari uraian diatas bisa diketahui bahwa jumlah pelanggan Poultry Shop Barokah selalu mengalami peningkatan pertahunnya, hal ini dikarenakan pelanggan yang baru gabung lebih banyak di bandingkan pelanggan yang keluar, maka dari angka tersebut bisa diambil kesimpulan bahwa perusahaan masih dalam kategori baik dalam mempertahankan retensi pelanggan yang pernah dicapai 
Tabel 5. Rasio pelanggan yang keluar

\begin{tabular}{|l|l|l|l|l|l|}
\hline Tahun & 2013 & 2014 & 2015 & 2016 & 2017 \\
\hline $\begin{array}{l}\text { Jumlah } \\
\text { Pelanggan }\end{array}$ & 81 & 82 & 84 & 90 & 93 \\
\hline $\begin{array}{l}\text { Pelanggan } \\
\text { Keluar }\end{array}$ & 6 & 4 & 5 & 7 & 3 \\
\hline $\begin{array}{l}\text { Rasio } \\
\text { karyawan } \\
\text { yang keluar }\end{array}$ & $0,07 \%$ & $0,05 \%$ & $0,06 \%$ & $0,08 \%$ & $0,03 \%$ \\
\hline
\end{tabular}

\section{c) Akuisisi Pelanggan}

Pengukuran ini dilakukan agar dapat diketahui tingkat dimana perusahaan mampu menarik berapa banyak pelanggan baru dengan cara membandingkan jumlah pelanggan dari tahun sebelumnya dengan tahun berikutnya. Untuk lebih jelasnya berikut adalah tabel dari akuisisi pelanggannya :

Tabel 6. Akuisisi Pelanggan

\begin{tabular}{|l|c|c|}
\hline Tahun & Jumlah Pelanggan & Akuisisi Pelanggan \\
\hline 2013 & 81 & 6 \\
\hline 2014 & 82 & 5 \\
\hline 2015 & 84 & 7 \\
\hline 2016 & 90 & 13 \\
\hline 2017 & 93 & 6 \\
\hline
\end{tabular}

d) Kepuasan Pelanggan

kepuasan pelnaggan merupakan sesuatu yang penting bagi keberlangsungan perusahaan karena dengan mengukur kepuasan pelanggan maka dapat diketahui seberapa baik kinerja pelayanan terhadap pelanggan. Berikut adalah hasil data dari kuisioner yang sudah dibagikan kepada pelanggan :

Tabel 7. Nilai Kuesioner Kepuasan Pelanggan

\begin{tabular}{|l|l|c|c|}
\hline $\begin{array}{l}\text { Penilaian } \\
\text { Responden }\end{array}$ & $\begin{array}{l}\text { Nilai } \\
\text { (1) }\end{array}$ & $\begin{array}{l}\text { Jumlah Jawaban } \\
\text { Responden (2) }\end{array}$ & $\begin{array}{l}\text { Tabel Nilai } \\
\text { (3)= (1) x (2) }\end{array}$ \\
\hline Sangat tidak puas & 1 & 2 & 2 \\
\hline Kurang puas & 2 & 13 & 26 \\
\hline Cukup puas & 3 & 85 & 255 \\
\hline Puas & 4 & 124 & 896 \\
\hline Sangat puas & 5 & 16 & 859 \\
\hline \multicolumn{2}{|c|}{ Jumlah } & 240 & \\
\hline
\end{tabular}

Dengan jumlah populasi pelanggan tahun 2017 yang ada di Poultry Shop Barokah adalah sejumlah 93 pelanggan maka, dapat diambil sampel sebanyak 49 pelanggan. Perhitungan ini berdasarkan rumus penentuan sampel yang telah dikemukakan oleh Sugiyono (2012) dengan perhitungan rumusnya: Tabel 8. Penilaian Responden

$$
\begin{aligned}
\mathrm{n} & =\frac{\mathrm{N}}{1+\mathrm{N} \cdot \mathrm{e}^{2}} \\
\mathrm{n} & =\frac{93}{1+93(0,1)^{2}} \\
& =48,18 \\
& =49 \text { karyawan (dibulatkan) }
\end{aligned}
$$

Dari hasil kuesioner sebanyak 49 pelanggan dan terdiri dari 5 item pertanyaan dengan skor 1 sampai 5 . Hasil diatas telah menunjukkan bahwa kepuasan pelanggan berada pada tingkat "Puas" dengan tabel tertinggi adalah 496.

$$
\begin{aligned}
& 240-432=\text { Dikategorikan sangat tidak puas } \\
& 433-624=\text { Dikategorikan tidak puas } \\
& 625-816=\text { Dikategorikan cukup puas } \\
& 817-1008=\text { Dikategorikan puas } \\
& 1009-1200=\text { Dikategorikan sangat puas }
\end{aligned}
$$

Dari perhitungan diatas berarti pelanggan sudah termasuk dalam kategori "puas" dimana nilai yang diperoleh berada pada interval 817 sampai 1008.

\section{Perspektif Bisnis Internal}

Berikut adalah hasil dari kuesioner perspektif bisnis internal yang sudah dibagikan:

Tabel 9. Nilai kuesioner perspektif bisnis internal

\begin{tabular}{|l|c|c|c|}
\hline $\begin{array}{l}\text { Penilaian } \\
\text { Responden }\end{array}$ & Nilai (1) & $\begin{array}{l}\text { Jumlah } \\
\text { Jawaban } \\
\text { Responden } \\
\text { (2) }\end{array}$ & $\begin{array}{l}\text { Tabel Nilai } \\
\text { (3)= (1) x (2) }\end{array}$ \\
\hline $\begin{array}{l}\text { Sangat tidak } \\
\text { baik }\end{array}$ & 1 & 3 & 3 \\
\hline Kurang baik & 2 & 29 & 58 \\
\hline Cukup baik & 3 & 173 & 519 \\
\hline Baik & 4 & 91 & 364 \\
\hline Sangat baik & 5 & 4 & 20 \\
\hline \multicolumn{2}{|c|}{ Jumlah } & 300 & 964 \\
\hline
\end{tabular}

Dari data tersebut telah menunjukkan bahwa penilaian tertinggi yaitu pada nilai 519 dengan artian "Baik". Dengan hasil tersebut maka dapat disimpulkan perspektif bisnis internal pada perusahaan dalam kategori baik.

4. Perspektif Pertumbuhan dan Pembelajaran

a) Kepuasan Karyawan

Indikator tolok ukur karyawan yang merasa puas ini di ukur dengan membagikan kuesioner kepada seluruh karyawan Poultry Shop Barokah sebanyak 147 karyawan. Berikut adalah hasil dari kuesioner perspektif pertumbuhan dan pembelajaran dan sudah dibagikan :

(Kaplan, Robert, S., \& Norton, David, 2001)

\begin{tabular}{|l|c|c|c|}
\hline $\begin{array}{l}\text { Penilaian } \\
\text { Responden }\end{array}$ & $\begin{array}{l}\text { Nilai } \\
\text { (1) }\end{array}$ & $\begin{array}{l}\text { Jumlah jawaban } \\
\text { responden (2) }\end{array}$ & $\begin{array}{l}\text { Tabel nilai } \\
\text { (3)= (1) x (2) }\end{array}$ \\
\hline $\begin{array}{l}\text { Sangat Tidak } \\
\text { Baik (STB) }\end{array}$ & 1 & 196 & 196 \\
\hline Tidak baik (TB) & 2 & 431 & 862 \\
\hline Cukup baik (CB) & 3 & 87 & 261 \\
\hline Baik (B) & 4 & 18 & 72 \\
\hline Sangat baik (SB) & 5 & 3 & 14 \\
\hline \multicolumn{2}{|c|}{ Jumlah } & 735 & 1406 \\
\hline
\end{tabular}


b) Retensi Karyawan

Retensi karyawan digunakan untuk melihat bagaimana karyawan dapat bertahan di perusahaan, degan cara membagi jumlah total karyawan keluar dengan total karyawan yang masih bekerja. (Kaplan, Robert, S., \& Norton, David, 1996)

Tabel 10. Rasio karyawan yang keluar

\begin{tabular}{|l|l|l|l|l|l|}
\hline Tahun & $\mathbf{2 0 1 3}$ & $\mathbf{2 0 1 4}$ & $\mathbf{2 0 1 5}$ & $\mathbf{2 0 1 6}$ & $\mathbf{2 0 1 7}$ \\
\hline $\begin{array}{l}\text { Jumlah } \\
\text { Karyawan }\end{array}$ & 120 & 123 & 144 & 145 & 147 \\
\hline $\begin{array}{l}\text { Karyawan } \\
\text { Keluar }\end{array}$ & 5 & 9 & 7 & 3 & 2 \\
\hline $\begin{array}{l}\text { Rasio } \\
\text { Karyawan } \\
\text { Yang Keluar }\end{array}$ & $0,04 \%$ & $0,07 \%$ & $0,04 \%$ & $0,02 \%$ & $0,01 \%$ \\
\hline
\end{tabular}

c) Produktivitas Karyawan

Tujuan dari indikator produktivitas ini adalah untuk mengetahui atau mengukur seberapa besar peningkatan produktivitas perusahaan dengan cara membandingkan pendapatan perusahaan dengan total jumlah karyawan (Mulyadi, 2001)

Tabel 11. Produktivitas karyawan

\begin{tabular}{|l|l|l|l|}
\hline \multicolumn{2}{|c|}{ Indikator Pengukuran } & $\begin{array}{l}\text { Produktifitas } \\
\text { karyawan }\end{array}$ & $\begin{array}{l}\text { Prosentase } \\
\text { karyawan }\end{array}$ \\
\hline \multirow{4}{*}{ Tahun } & 2013 & Rp 58.333.333 & $100 \%$ \\
\cline { 2 - 4 } & 2014 & Rp 65.040 .650 & $111 \%$ \\
\cline { 2 - 4 } & 2015 & Rp 59.027.777 & $101 \%$ \\
\cline { 2 - 4 } & 2016 & Rp 62.068 .965 & $106 \%$ \\
\cline { 2 - 4 } & 2017 & Rp 71.428.571 & $122 \%$ \\
\hline
\end{tabular}

PENUTUP

Berdasarkan hasil penelitian dan pembahasan pada penelitian ini dapat diambil kesimpulan sebagai berikut :

1. Pada Poultry Shop Barokah telah dilakukan pengukuran kinerja dengan menggunakan pendekatan Balanced Scorecard yang terdiri dari empat perspektif yaitu Perspektif Pelanggan, Perspektif Keuangan, Perspektif Bisnis Internal, Perspektif Pertumbuhan dan Pembelajaran.

2. Faktor kontribusi yang mempengaruhi Poultry Shop Barokah yaitu terdiri dari 14 tolok ukur dan yang telah memenuhi penilaian yaitu 9 tolok ukur dari indikator Balanced Scorecard. Sedangkan yang tidak tercapai dari indikator Balanced Scorecard terdapat 5 tolok ukur. Jadi dari hasil presentase kinerja yang dicapai Poultry Shop Barokah yaitu berada di persentase 64,3\% dengan kategori “Baik".

\section{DAFTAR PUSTAKA}

Fadillah, N., Arizon, M., Adriansyah, G., Fudhla, A. F., \& Dwi, A. (2019). Performance Measurement in CV . Sinar Energi Gemilang with Balanced Scorecard Method Performance Measurement in CV . Sinar Energi Gemilang with Balanced Scorecard Method. Journal of Physics Conferences Series. https://doi.org/10.1088/17426596/1175/1/012286

Kaplan, Robert, S., \& Norton, David, P. (1992). The Balanced Scorecard-Measures That Drive Performance, Harvard Business Review.

Kaplan, Robert, S., \& Norton, David, P. (1996). The Balanced Scorecard: Translating Strategy Into Action. Massachusetts,Harvard Business School Press.

Kaplan, Robert, S., \& Norton, David, P. (2001). The Strategy Focused Organization: How Balanced Scorecard Companies Thrive in the New Business Environment.

Mulyadi. (2001). Balanced Scorecard. Yogyakarta: Salemba Empat.

Mulyadi dan Setyawan Johny. (2000). Sistem Perencanaan dan Pengendalian Persahaan, Edisi Kedua. Jakarta: Salemba Empat.

Nair, M. (2014). Essentials Of Balanced Scorecard (Essentials Series). Jakarta: Wiley.

Sumanto. (1995). Metodologi Sosial dan Pendidikan. Yogyakarta: Andi Offset.

Widjaja. (2001a). Memahami Konsep Balanced Scorecard. Jakarta: Harvalindo.

Widjaja. (2001b). Pengukuran Konerja Dengan Balanced Scorecard. Jakarta: Harvalindo. 